\title{
Islands of Mytilus as a habitat for small intertidal animals: effect of island size on community structure*
}

\author{
M. Tsuchiya ${ }^{1 * *} \&$ M. Nishihira ${ }^{2 * *}$ \\ ${ }^{1}$ Marine Biological Station, Tohoku University, Asamushi, Aomori 039-34, Japan \\ ${ }^{2}$ Laboratory of Animal Ecology, Kyoto University, Kyoto 606, Japan
}

\begin{abstract}
Patches of Mytilus edulis L. composed of similar sized mussels were surveyed in order to investigate the effect of patch size on community structure of associated animals. Each patch included common components such as byssus, shell fragments, sediments, algae and associated animals. Volume of each component increased with patch size. With increasing patch size, species richness and number of individuals of associated animals increased, but decreased per unit patch size. Patch area affected population density more than patch volume. Volume of associated animals per unit patch area was relatively constant, but volume per unit patch volume decreased with increasing patch size. Mean body width of the polychaete Typosyllis adamanteus kurilensis Chlebovitsh increased with patch size. Large individuals of the winkle Littorina brevicula Philippi were not found in smaller patches. At high tides, large numbers of the amphipod Hyale grandicornis Kröyer, which live among algae attached to the patches, were seen on rock surfaces covered by the barnacle Chthamalus challengeri Hoek around the patches. These results can be mainly explained in relation to accumulation of sediments and shell fragments of $M$. edulis in the patches, and the community structure of the Mytilus island is discussed with reference to species-area relations.
\end{abstract}

\section{INTRODUCTION}

Intertidal communities have been investigated from several points of view, e.g. prey-predator relations (Connell 1961a, b, 1970, 1972, Paine 1969, 1974, Dayton 1971, Menge 1976, etc.), grazing effect on algal populations (Paine \& Vadas 1969, Kitting 1980, Underwood 1980, Hawkins 1981, Underwood \& Jernekoff 1981, Nishihira et al. 1982) and structuring features of zonation (Southward 1958, Hoshiai 1960, 1965). An abundance of small animals live in patches of sessile organisms, and several workers have emphasized the important role of sessile organisms for small motile animals (Keith 1971, Paine 1971, Seed 1976, Dean 1981), but details of the relation between them have not been thoroughly clarified.

\footnotetext{
- Contribution No. 508 from Marine Biological Station Tohoku University; contribution No. 473 from Laboratory of Animal Ecology, Kyoto University

- Present address: Department of Biology, University of the Ryukyus, Nishihara, Okinawa 903-01، Japan
}

The mussel Mytilus edulis L. forms patches or beds and creates a habitat for small animals including polychaetes, amphipods and nemerteans (Tsuchiya 1979). Such patches, because they are isolated from similar patches, can be treated as islands for associated communities. For the sake of convenience, a patch of M. edulis is called a 'Mytilus island'. A Mytilus patch can be used as an ecological tool for island studies. Patch size and habitat structure such as age structure of the constituent mussels can be quantified easily and their effects on community structure analysed. In marine environments, island models, sometimes designated as 'marine mini-islands' (Schoener 1974b), have been studied for sponges (Pearse 1950, Westinga \& Hoetjes 1981) and corals (Abele 1976, 1979, Gotelli \& Abele 1983). Similar investigations were also performed using submerged artificial plates (Schoener 1974a, Osman 1978, Schoener et al. 1978), dried sponge (Frith 1976), or plastic-mesh sponge (Schoener $1974 \mathrm{~b}$ ). Although there are a great variety of marine mini-islands, only a few studies have been performed. None have been devoted to Mytilus islands. 
Theories of species-area relations have been developed using island ecosystems (MacArthur \& Wilson 1967, MacArthur 1972, Williamson 1981, etc.). It is generally accepted that larger islands support more species and that species richness is positively correlated with environmental heterogeneity. However, it is necessary to distinguish heterogeneity and area for analytical discussion of species-area relations. For such a study, Mytilus islands can serve as a model because they are easy to handle and the substantial heterogeneity can be manipulated.

The aim of the present study was to examine the ecological property of island size measured as the area of a Mytilus patch.

\section{MATERIALS AND METHODS}

Mytilus edulis patches were selected on a gently sloping $\left(10^{\circ}\right.$ ) artificial (concrete) surface at 70 to $80 \mathrm{~cm}$ above MLWS at a small harbor at the Marine Biological Station, Tohoku University $\left(40^{\circ} 55^{\prime} \mathrm{N}, 140^{\circ} 50^{\prime} \mathrm{E}\right)$. Twenty-four mussel patches of various sizes were photographed, measured for length, width and height and then scraped off altogether with a spatula at low tide. Where the brown alga Sargassum thunbergii was attached to mussel shells, it was removed first and stored separately from the patch samples. After scraping, the displacement volume of each patch was measured by wrapping it in a thin polyethylene sheet. Then the volumes of each constituent, i.e. $M$. edulis, byssus outside shells, shell fragments, sediments (remnants after collecting the shell fragments), algae attaching to mussels (e.g. Chondria crassicaulis and Laurencia okamural), and associated animals, were similarly measured. Size of mussels was recorded and associated animals were identified and counted for each patch. Sizes of some frequent species, e.g. the polychaete Typosyllis adamanteus kurilensis, the winkle Littorina brevicula and the limpet Collisella (Conoidacmea) heroldi, were measured. Space around each patch was covered by the barnacle Chthamalus challengeri (coverage of 5 to $80 \%$ ), with some $C$. heroldi and $L$. brevicula on the bare rock surface. Sizes of C. heroldi and $L$. brevicula in and outside the patches were measured. At high tides, the amphipod Hyale grandicornis and the isopod Dynoides dentisinus, which appeared around the patches, were counted. Some young specimens of the mussel Septifer virgatus ( $<5 \mathrm{~mm}$ long), which are also common on the natural rocky intertidal (Hoshiai 1965, Tsuchiya 1979), were found in some patches. All samplings were made during daytime low tides in June.

\section{RESULTS \\ Ecological traits of Mytilus islands and their communities \\ Habitat characteristics of Mytilus patches}

Table 1 shows size and volume of each component for each Mytilus patch. Generally, the volume of each component except of algae increased with patch size. All shell fragments were those of young $M$. edulis. A few complete shells were found mainly in larger patches (Patches $A, B, C, E$ ). In order to discuss the relation between size of Mytilus island and its associated fauna, 2 thalli of Sargassum thunbergii (11 and 16 $\mathrm{cm}$ long) in Patch $A$ and 3 (7, 9 and $17 \mathrm{~cm}$ long) in $B$ were removed before scraping and not included in Table 1. Many amphipods including Hyale grandicornis and Jassa falcata, and the epiphytic small gastropod Temanella turrita, were seen on these algae but also not included. Most of the remaining algae were the small red algae Chondria crassicaulis and Laurencia okamurai, and short $S$. thumbergii (in A and B: $<2$ $\mathrm{cm}$ long, in others: $<1 \mathrm{~cm}$ long). These algae were included in Table 1.

There were many solitary Mytilus edulis, which did not accumulate sediments and shell fragments, and did not support algae and associated animals.

\section{Size distribution of Mytilus edulis}

Fig. 1 shows the size distribution of Mytilus edulis for each patch. All the patches had similar size compositions dominated by small mussels ( $<10 \mathrm{~mm}$ long). Patches D and I, however, also had large mussels (25 to $40 \mathrm{~mm}$ long) and displayed a bimodal distribution. Solitary individuals were smaller ( $<10 \mathrm{~mm}$ long). Patches with a similar size composition varied greatly in their heights (Table 1), because the mussels become multilayered in larger patches. Patch D included 160 Septifer virgatus. However, because these were smaller ( $<5 \mathrm{~mm}$ long) than the $M$. edulis, it retained the superficial appearance of a Mytilus island. In other patches, $S$. virgatus was very few or lacking.

\section{Motile animals living in Mytilus patches}

Table 2 shows the numbers of animals found in each patch. The flatworm Notoplana humilis was most abundant in the 2 largest patches (A \& B), but only a few individuals were found in the medium patches $(C$, $D, F, G, H)$, and none were found in small patches. 
Table 1. Mytilus edulis. Patch size and volume of components

\begin{tabular}{|c|c|c|c|c|c|c|c|c|c|c|c|}
\hline \multirow[t]{2}{*}{ Patch } & \multicolumn{4}{|c|}{ Size of patches } & \multicolumn{7}{|c|}{ Volume of each component $\left(\mathrm{cm}^{3}\right)$} \\
\hline & $\begin{array}{l}\text { Length } \times \text { width } \\
\quad(\mathrm{cm} \times \mathrm{cm})\end{array}$ & $\begin{array}{l}\text { Area } \\
\left(\mathrm{cm}^{2}\right)\end{array}$ & $\begin{array}{l}\text { Height } \\
\text { (mm) }\end{array}$ & $\begin{array}{l}\text { Volume } \\
\left(\mathrm{cm}^{3}\right)\end{array}$ & $\begin{array}{l}\text { Mytilus } \\
\text { edulis }\end{array}$ & Byssus & $\begin{array}{l}\text { Sedi- } \\
\text { ments }\end{array}$ & $\begin{array}{l}\text { Shell } \\
\text { frag- } \\
\text { ments }\end{array}$ & Algae & Space & $\begin{array}{l}\text { Associ- } \\
\text { ated ani- } \\
\text { mals }\end{array}$ \\
\hline A & $30 \times 24$ & 521.3 & 28.0 & 1162.0 & 477.2 & 6.5 & 40.6 & 17.5 & 9.8 & 605.2 & 5.2 \\
\hline$B$ & $20 \times 15$ & 230.6 & 24.0 & 674.0 & 319.2 & 3.4 & 31.9 & 4.9 & 16.2 & 295.6 & 2.8 \\
\hline C & $14 \times 13$ & 139.0 & 19.6 & 220.0 & 109.0 & 0.7 & 1.6 & 0.6 & 1.0 & 104.4 & 2.7 \\
\hline D & $11 \times 8.5$ & 74.7 & 26.4 & 133.1 & 84.6 & 0.5 & 1.1 & 1.9 & 0.1 & 82.8 & 2.1 \\
\hline$E$ & $10 \times 8.5$ & 70.9 & 19.0 & 105.1 & 50.3 & 0.3 & 0.7 & 0.6 & 0.8 & 51.7 & 0.7 \\
\hline$F$ & $9.5 \times 7$ & 56.2 & 20.3 & 82.1 & 50.0 & 0.6 & 2.9 & 0.4 & 0.3 & 26.8 & 1.1 \\
\hline G & $11 \times 6$ & 52.0 & 17.5 & 96.7 & 48.0 & 0.2 & 0.4 & 0.1 & 0.8 & 45.6 & 1.6 \\
\hline $\mathrm{H}$ & $10 \times 6$ & 45.9 & 13.4 & 45.2 & 21.3 & 0.2 & 0.7 & 0.5 & 0.5 & 21.0 & 1.0 \\
\hline I & $8 \times 6$ & 35.2 & 19.0 & 48.0 & 25.4 & 0.2 & 0.4 & 0.3 & 0.1 & 20.8 & 0.9 \\
\hline $\mathrm{J}$ & $8 \times 5$ & 30.3 & 14.3 & 41.4 & 15.1 & 0.2 & 0.2 & 0.2 & 0.3 & 24.9 & 0.5 \\
\hline $\mathrm{K}$ & $7.5 \times 5$ & 28.2 & 12.0 & 32.0 & 18.2 & 0.2 & 0.3 & 0.2 & 0.2 & 12.1 & 1.0 \\
\hline $\mathrm{L}$ & $6.5 \times 5$ & 24.2 & 13.8 & 34.0 & 15.6 & 0.1 & 0.5 & 0.3 & 0.5 & 16.4 & 0.6 \\
\hline$M$ & $6 \times 4.5$ & 23.3 & 12.0 & 26.5 & 11.0 & 0.1 & 0.2 & 0.2 & 1.0 & 12.8 & 1.2 \\
\hline $\mathrm{N}$ & $5 \times 4.5$ & 18.6 & 10.5 & 15.3 & 7.9 & 0.1 & 0.2 & 0.1 & 0.4 & 6.1 & 0.5 \\
\hline 0 & $5.5 \times 3$ & 13.0 & 7.5 & 8.5 & 4.4 & $<0.1$ & $<0.1$ & $<0.1$ & 0.3 & 3.4 & 0.3 \\
\hline $\mathrm{P}$ & $4 \times 3$ & 9.1 & 8.5 & 15.6 & 4.8 & $<0.1$ & $<0.1$ & 0.1 & 0.2 & 10.0 & 0.5 \\
\hline$Q$ & $3.5 \times 2.5$ & 6.6 & 7.5 & 5.0 & 2.0 & $<0.1$ & $<0.1$ & $<0.1$ & 0.1 & 2.7 & 0.1 \\
\hline $\mathrm{R}$ & $2 \times 1.8$ & 2.8 & 7.0 & 2.1 & 0.9 & $<0.1$ & $<0.1$ & $<0.1$ & $<0.1$ & 0.8 & 0.1 \\
\hline $\mathrm{S}$ & $2 \times 1.4$ & 2.4 & 7.0 & 1.8 & 0.6 & $<0.1$ & $<0.1$ & $<0.1$ & $<0.1$ & 1.0 & $<0.1$ \\
\hline $\mathrm{T}$ & $1.8 \times 1.6$ & 2.3 & 6.0 & 1.7 & 0.9 & $<0.1$ & 0 & $<0.1$ & $<0.1$ & 0.6 & $<0.1$ \\
\hline U & $1.9 \times 1.3$ & 2.0 & 9.0 & 1.5 & 0.6 & $<0.1$ & $<0.1$ & $<0.1$ & 0.1 & 0.6 & $<0.1$ \\
\hline V & $2.2 \times 1.1$ & 1.9 & 7.0 & 1.8 & 1.0 & $<0.1$ & $<0.1$ & $<0.1$ & 0 & 0.6 & $<0.1$ \\
\hline W & $1.7 \times 1.1$ & 1.2 & 10.0 & 1.7 & 0.8 & $<0.1$ & $<0.1$ & $<0.1$ & 0 & 0.7 & 0.1 \\
\hline$x$ & $0.8 \times 0.7$ & 0.4 & 5.0 & 0.5 & 0.2 & $<0.1$ & 0 & 0 & 0 & 0.3 & 0 \\
\hline
\end{tabular}

Nemerteans were not as abundant, but occurred in many patches although not in the smaller ones.

Polychaetes appeared in most patches and were abundant both as individuals and as species. Abundance was not highly correlated with patch size, e.g. numbers of both individuals and species in D, E and F were less than those in $\mathrm{G}$ and $\mathrm{H}$. This was caused by density differences in the syllid Typosyllis adamanteus kurilensis. This species was most abundant, appearing in many patches, but fewer in Patches $D, E$ and $F$ than in $\mathrm{G}$ and $\mathrm{H}$. The nereid Perinereis cultrifera was common in many patches but not found in the 2 largest.
Fig. 1. Mytilus edulis. Size distribution for each Mytilus patch. N: total number of individual $M$. edulis (Septifer virgatus). S. virgatus were small $(<5 \mathrm{~mm}$ long) and not included in histograms. A to $X$ : patch names

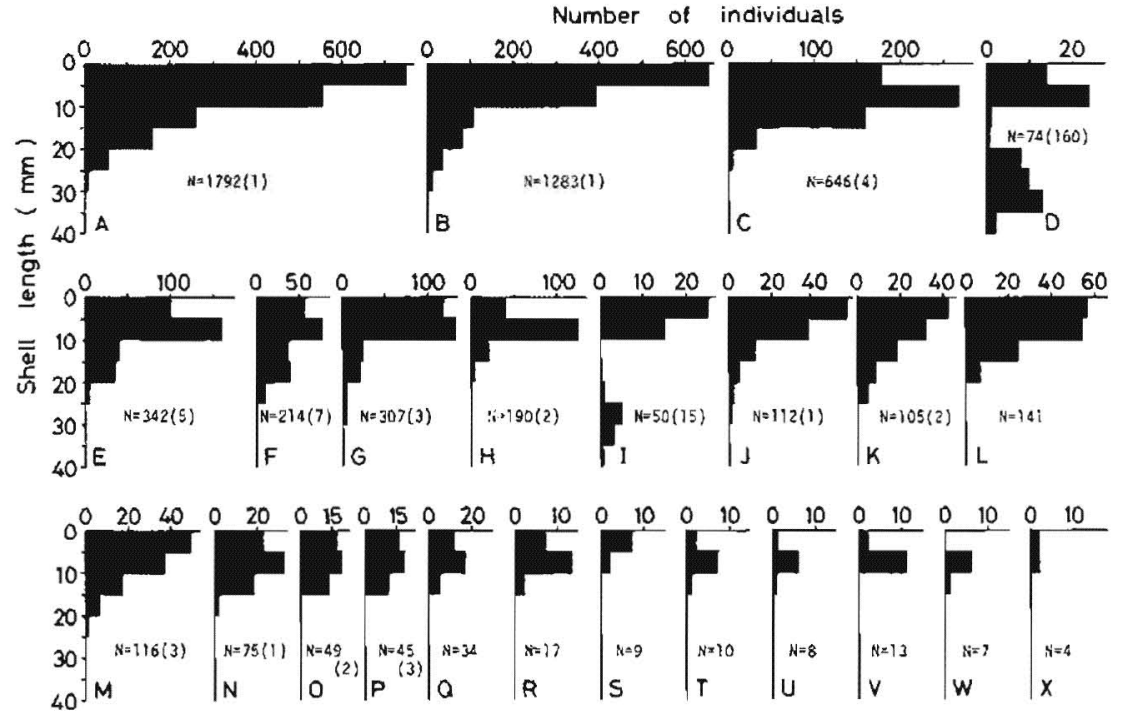




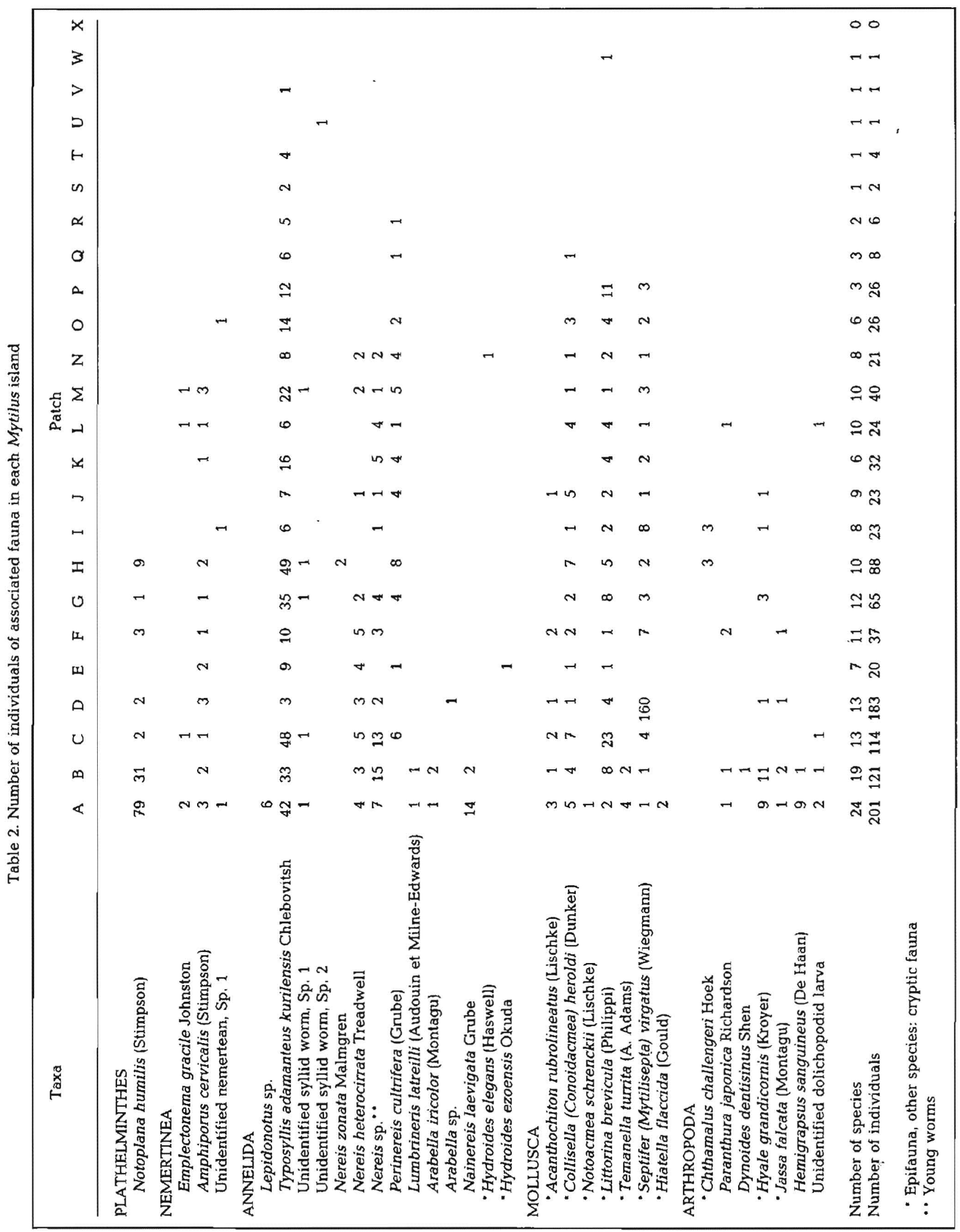


The orbinid Nainereis laevigata was abundant but restricted to the 2 largest patches.

Gastropods, mostly epifauna, occurred in many patches including smaller ones, but were never abundant. The winkle Littorina brevicula and the limpet Collisella heroldi were commonest and the gastropod Temanella turrita lived on Sargassum tunbergii attached to Mytilus edulis shells. Crustaceans were abundant in the 2 largest patches, where the amphipod Hyale grandicornis and/or the young crab Hemigrapsis sanguineus were dominant. Smaller patches did not support these crustaceans.

Motile animals around Mytilus patches

The areas around Mytilus patches were surveyed at low (Table 3a) and high tides (Table 3b). The surface was covered by the barnacle Chthamalus challengeri,

Table 3. (a) Densities (range, mean $\pm \mathrm{SD}$ ), of animals per $10 \mathrm{~cm} \times 10 \mathrm{~cm}$ observed close to Mytilus islands at low tide.

(b) Additional animals seen at high tide

(a)

$\begin{array}{lrrr}\text { Chthamalus challengeri" } & 16-448 & (123.8 \pm 154.7) \\ \text { Littorina brevicula } & 3-61 & (38.0 \pm & 24.8) \\ \text { Collisella (Conoidacmea) heroldi } & 2-14 & (5.0 \pm & 4.5) \\ \text { - Coverage } 5-80 \% & & & \end{array}$

(b)

$\begin{array}{lll}\text { Hyale grandicornis } & 0-7 & (1.5 \pm 1.8) \\ \text { Dynoides dentisinus } & 0-12 & (2.6 \pm 2.9)\end{array}$

and the winkle Littorina brevicula lived among the barnacles or in the empty barnacle shells. The small limpet Collisella heroldi also seen in Mytilus patches was found among the barnacles and on bare surfaces. At high tides, the amphipod Hyale grandicornis appeared outside the patches and moved with water movements. The small isopod Dynoides dentisinus, seen in lower intertidal mussel beds at low tides (Tsuchiya unpubl.), was also found among the barnacles and on the bare surfaces.

\section{Patch size vs associated fauna}

Patch size vs species richness

Fig. 2 shows the relation between patch size (area and volume) and number of species (epifaunal, crypticfaunal, and total). Species richness increased with patch size, but species density $\left(\mathrm{Scm}^{-2}\right.$ or $\left.\mathrm{Scm}^{-3}\right)$ decreased with patch size. Similar trends were recognized for patch area and for patch volume.

Patch size vs population size

Fig. 3 shows the relation between patch size and number of individuals. Again, numbers increased with patch size and as before, the reverse trend was true for density $\left(\mathrm{Ncm}^{-2}\right.$ or $\left.\mathrm{Ncm}^{-3}\right)$. Abundance is better described by patch volume than by patch area. Although a similar trend appeared for patch area and volume of associated animals (Fig. 4), volume of associated animals per unit patch size was correlated less with area (Fig. 4a) than with volume (Fig. 4b) of patches.

\section{Patch size vs species diversity}

Fig. 5 shows the relation between patch size and species (total, epifaunal and cryptic-faunal) diversity expressed by the Shannon-Weaver Index $\left(\mathrm{H}^{\prime}\right)$. All diversities increased simply with patch size.

\section{Size distribution of some animals}

Size distribution of the endobenthic polychaete Typosyllis adamanteus kurilensis is shown in Fig. 6. Mean body width increased with patch size. It was abundant in Patches A, B, C, G and H, where body size showed great variation, while in small patches, except $M$, only small worms were found (Fig. 6). In Patch $M$, several large worms were found among many small ones.

Littorina brevicula was observed in most patches, but was most abundant in Patches $C$ and $P$, the latter supporting only small individuals. Among patches smaller than $6.6 \mathrm{~cm}^{2}$, it was seen only in $W$ which supported a single small individual. Large snails were found only in larger patches. Small winkles (shell height: 2.0 to $4.5 \mathrm{~mm}$ ) living among the barnacles adjacent to Mytilus patches were common and size composition was comparable between those living in and outside patches; shell height was $3.82 \pm 0.92 \mathrm{~mm}$ (mean $\pm \mathrm{SD}, \mathrm{n}=82$ ) for those in, and $3.51 \pm 0.65 \mathrm{~mm}$ $(n=230)$ for those outside patches.

Collisella heroldi was rather scarce and its abundance was not correlated with patch size. Probably because of its scarcity, size composition was quite variable, while that of the limpets around patches showed normal distribution. 

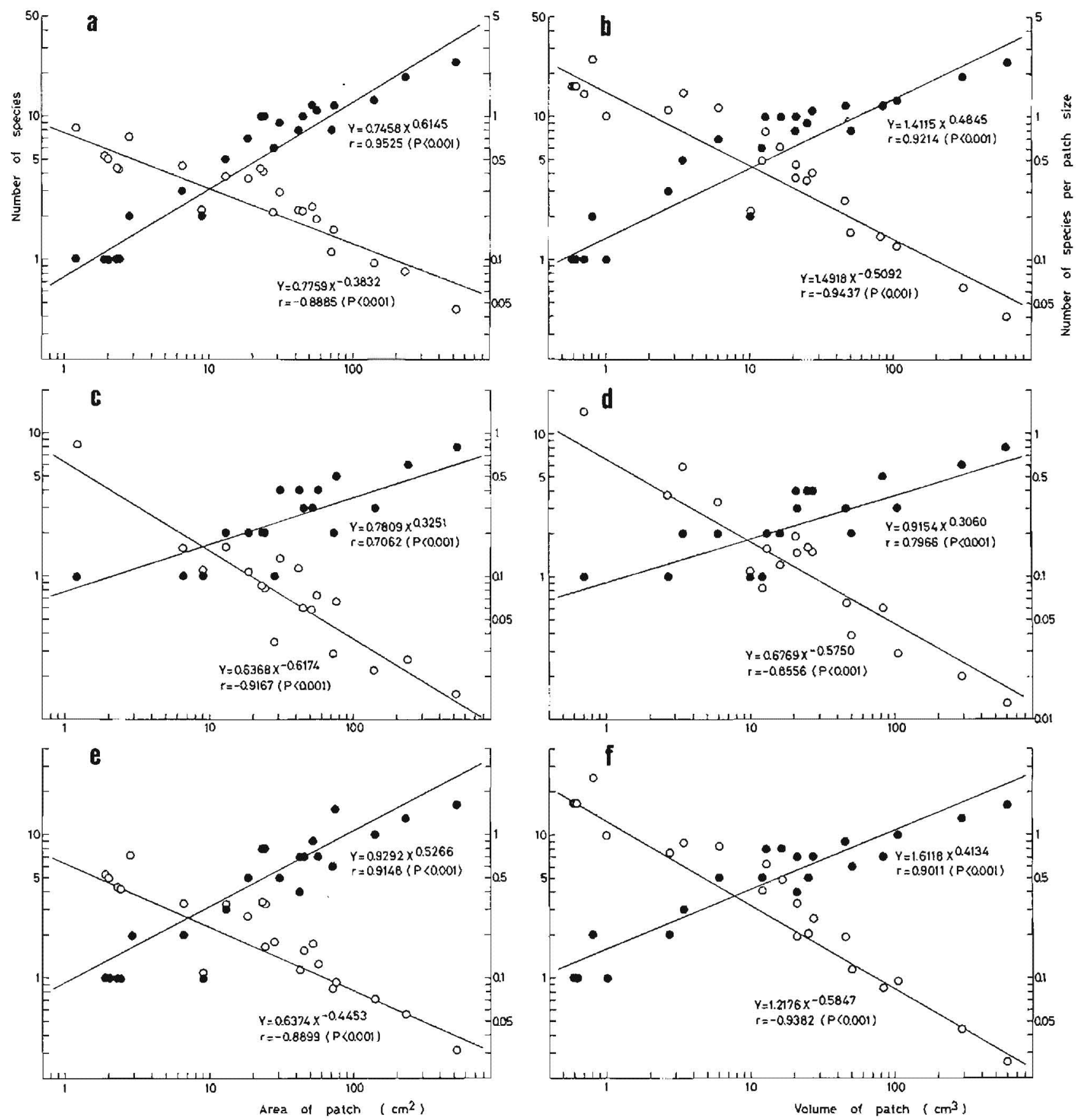

Fig. 2. Relations between patch size ( $a, c, e:$ area; $b, d, f:$ volume) and number of associated species ( $a$, b: total number of species); c, d: number of species of epifauna; e, $f$ : number of species of cryptic fauna). Solid circles: number of species; open circles: number of species per patch size

\section{DISCUSSION}

The internal structural complexity of a cluster of mussels increases through mussel growth, which in turn favors occupancy by a variety of small animals through creation of several microhabitats (Fig. 7). Unlike real islands, Mytilus patches include animals living around the island, and some inhabitants move outside the island at high tide. However, a Mytilus island has several merits as a tool for analysis of species-area relations, effects of island size on life of inhabitants, and heterogeneity of environments.

The islands studied here seem to be of similar age because the size distribution of mussels was similar 

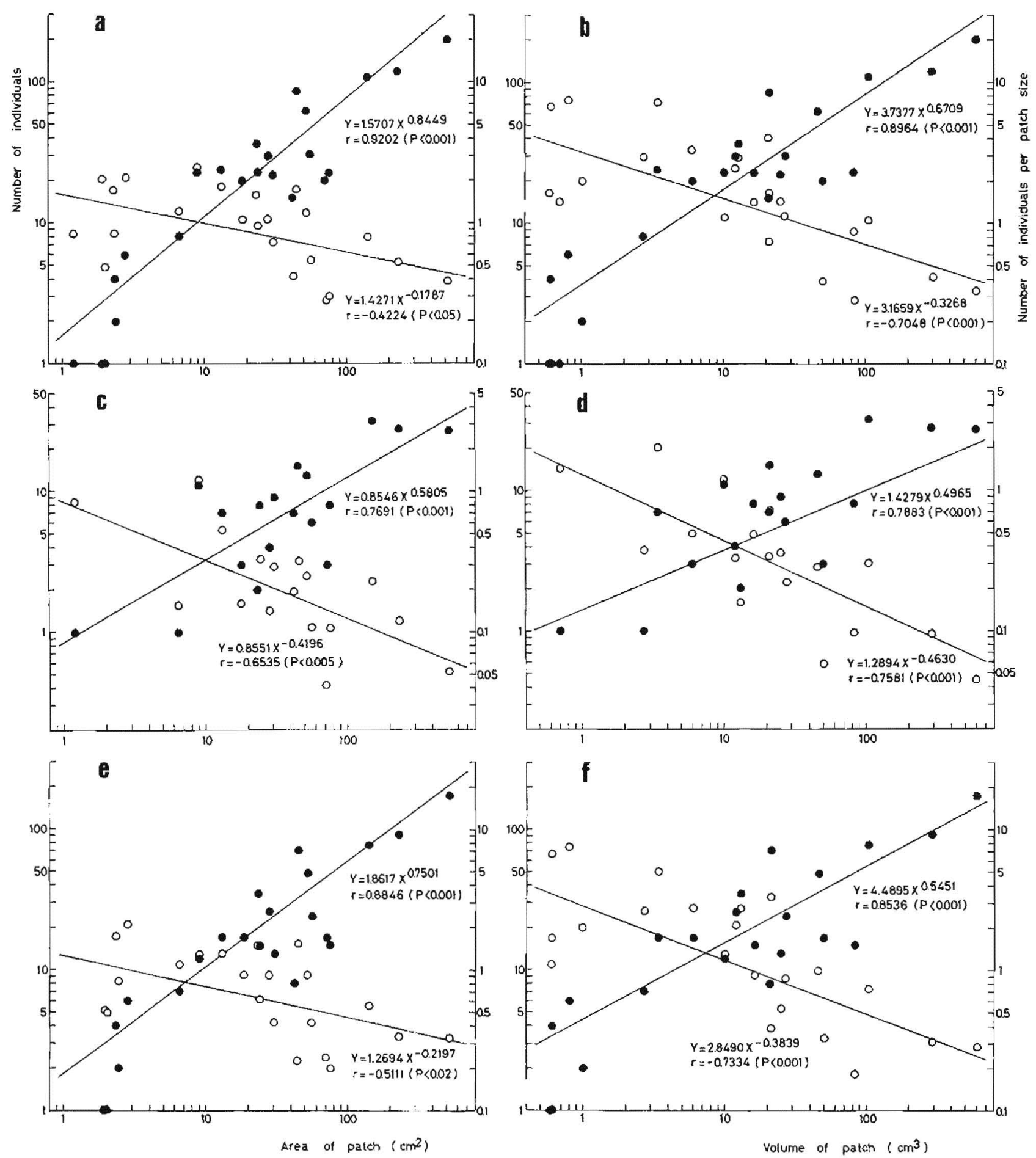

Fig. 3. Relations between patch size ( $a, c, e$ : area; $b, d$, f: volume) and number of indiviuals ( $a, b$ : total number of individuals; $c$, d: number of individuals of epifauna; $\mathrm{e}, \mathrm{f}$ : number of individuals of cryptic fauna). Solid circles: number of individuals; open circles: number of individuals per patch size

except in Patches D and I, which displayed a bimodel distribution (Fig. 1). Therefore, historical influence or time effect can be excluded from consideration. All the patches were sampled at a similar tide level. There- fore, community structure of the associated animals can be analyzed solely in relation to patch size.

It is generally accepted that environmental heterogeneity or variety of habitats increases with 

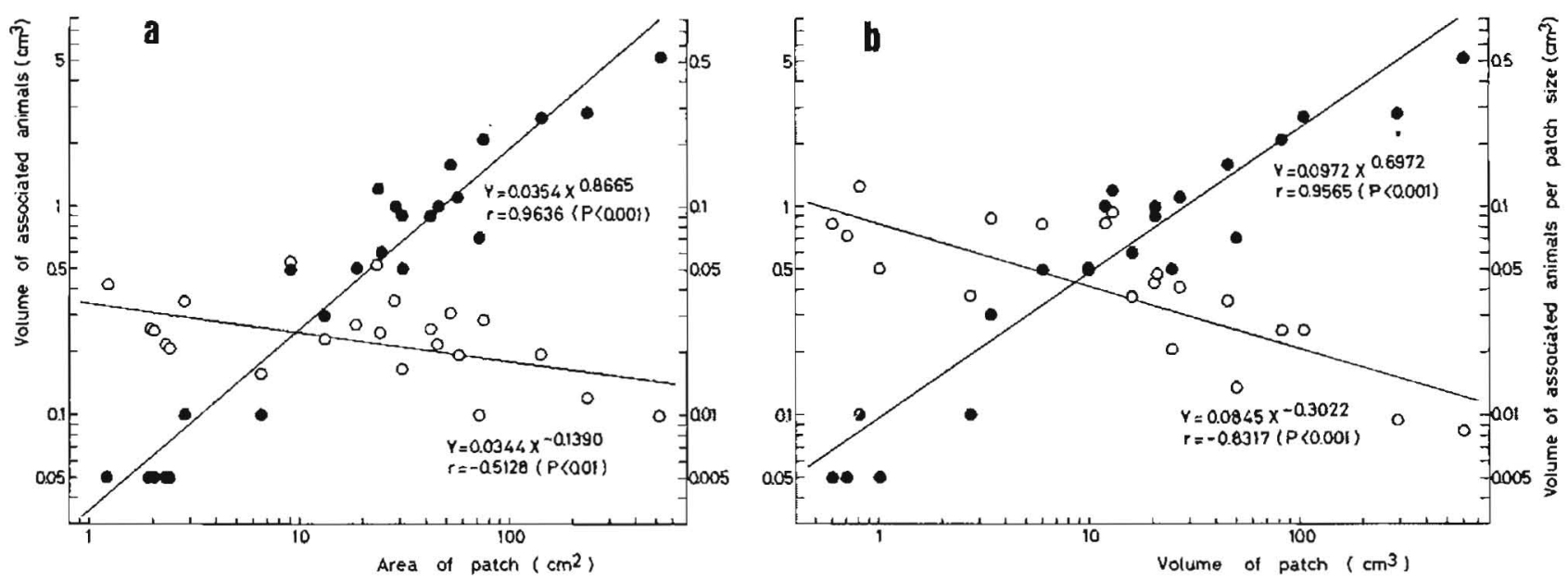

Fig. 4. Relations between patch size (a: area; b: volume) and volume of associated animals. Solid círcles: total volume of associated animals; open circles: volume of associated animals per patch size

island size and thus a larger island supports more species. This may be true for our Mytilus islands. All the Mytilus islands studied were composed of common components, i.e. shells, byssus, sediments, shell fragments and algae, but the amounts of these components differed with island size (Table 1). Detailed biological analysis of the heterogeneity is required for complete understanding of species-area relation. Sediments were particularly abundant in Patches A and B (Table 1). Undoubtedly the accumulation of sediments create new micro-habitats inside the patch, but it is also possible that a reducing condition is created by the accumulation of a large amount of sediment. Consequently, it may bring faunal change or even decreases in the density or diversity of associated animals. This phenomenon was observed in the intertidal community on a harbour breakwater (Tsuchiya 1979). There may also be some biological interactions between M. edulis and the associated animals, e.g. M. edulis produce large amounts of biodeposits (faeces and pseudofaeces) (Tsuchiya 1980). Because $M$. edulis attach one above another in larger patches, biodeposits produced by mussels attaching to deeper parts of the patch may accumulate inside the patch, as was already reported for Mytilus beds (Davies et al. 1980) and oyster reefs (Iund 1957), together with dead and decomposing associated animals. The fact that the scavenging flatworm Notoplana humilis was abundant only in larger patches may be in part a function of reduced water movement in the larger patches. Tsuchiya (1983) reported that mass mortality in $M$. edulis attracted the flatworms, which disappeared after the dead mussel tissues had been consumed. This suggests the presence of sufficient food for the flatworms in larger patches. Food may not be easy to accumulate in small patches. Although the effect of scavengers on species composition is unknown, absence of the nereid Perinereis cultrifera in such scavenger-dominated patches may be related to the presence of many flatworms.

The surface of Mytilus edulis shells and shell fragments serve as a substrate for bacteria, micro-algae and small animals. Detritus easily attaches to the shell surface. These may also support animals in the patches. Algal thalli attaching to the shells also support various animals including amphipods and gastropods. Increases in heterogeneity, if any, may be caused by increases in these components and in the amount of space among Mytilus edulis shells.

Community structure changes with time due to invasion and extinction of animals in each island. When settling on an island, there is a possibility that some larvae are eaten by the filter-feeding Mytilus edulis and some others may receive some biological effects, e.g. predation and competition, by earlier colonizers. Species richness increased with patch size (area and volume), and it may reach a plateau specific to the tide level. Decrease of species density with patch size may be caused by species endemic to larger patches suppressing other animals via predation or competition, or creating an unsuitable physico-chemical environments for other species. Such influential species may include the flatworm, Notoplana humilis, the nereid Nereis heterocirrata, the orbinid Nainereis laevigata and the grapsid crab Hemigrapsis sanguineus.

Westinga \& Hoetjes (1981), studying the relation between the sponge-inhabiting fauna and host size, reported that the biomass of associated animals per unit volume of sponge did not differ much relative to sponge size in larger sponges, but a greater variance of 
biomass was recognized in smaller ones. Animals in sponges generally are protected from water movement
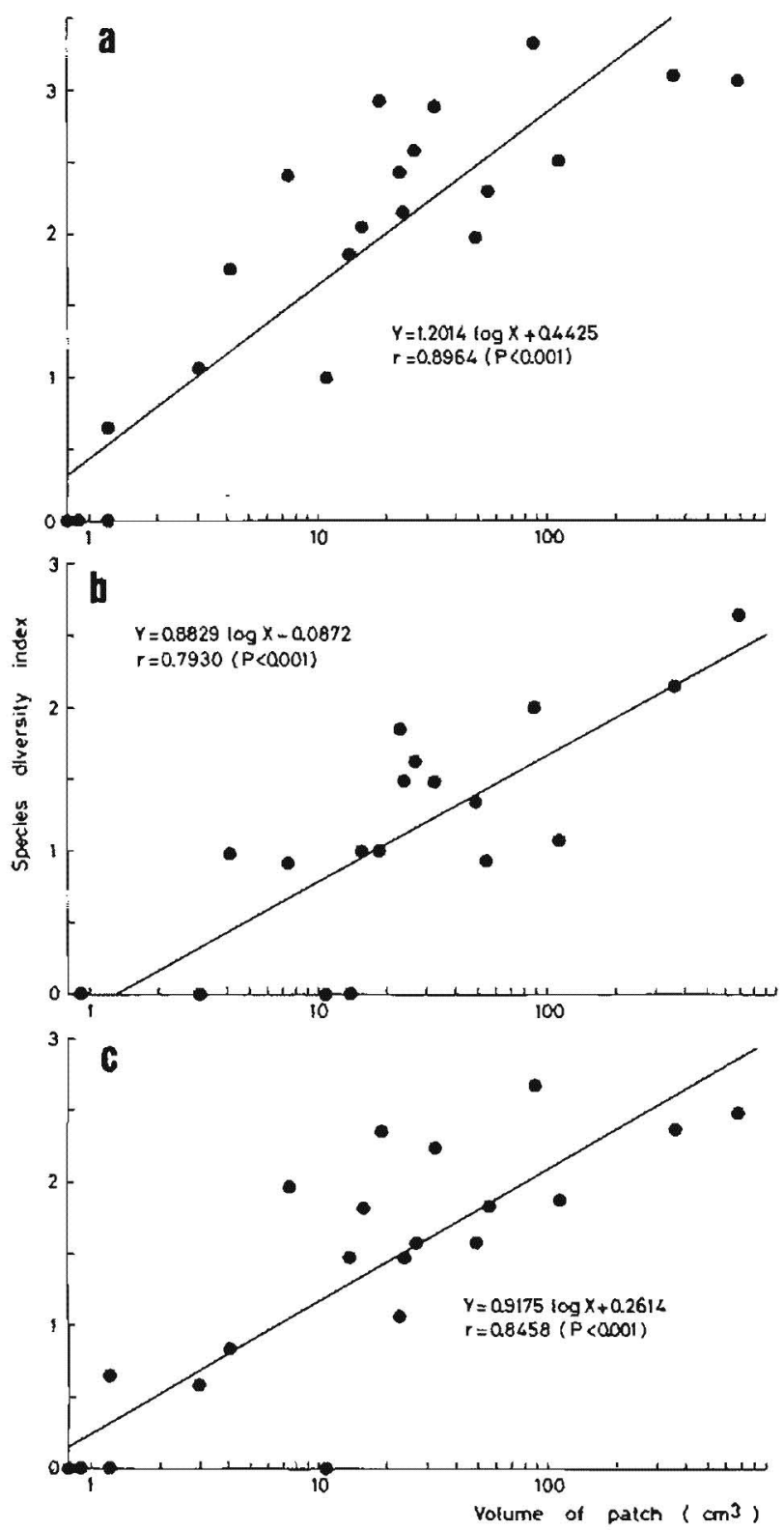

Fig. 5. Relations between species diversity, $H^{\circ}$, (a: total species; b: epifauna, c: cryptic fauna) and patch size (volume) or predation, and it was suspected that similar environments for all the associated animals were provided by larger sponges. Animals in smaller sponges may be affected by the more stressful environment. For Mytilus islands, the periphery has an environment different from the central part, probably created by different effects of wave action. The volume of associated animals per unit patch area was relatively constant irrespective of patch size. This suggests that the associated animals mainly inhabit the patch's lower layer, where sediments and shell fragments accumulate. Upper parts may be unsuitable especially for the cryptic fauna.

Actual mode of life of each species may be affected by patch size. Larger individuals of the syllid Typosyllis adamanteus kurilensis live only in larger patches (Fig. 6). Abundant food in larger patches may cause better growth and survival of this polychaete. On the contrary, smaller patches lacking shelter together with poor food are unsuitable for larger individuals. Increase of species diversity with patch size suggests that larger patches have greater heterogeneity of environments, which allow many species to inhabit them by providing suitable conditions for feeding or shelter from predators and wave action.

For epibenthic molluses, a Mytilus island is used as a resting site. Emson \& Faller-Fritsh (1976) reported that Littorina rudis frequently used crevices as their habitat, and experimental addition of crevices greatly increased population density, and suggested that crevice availability is normally a limiting factor. $L$. brevicula, especially smaller individuals, also use small spaces such as crevices, empty Chthamalus challengeri shells and Mytilus islands. It is suggested that larger winkles do not dwell in small patches due to the lack of large crevices (spaces among the mussels). This may explain the restriction of the large winkles to larger patches. However, this trend was not observed for Collisella heroldi and patch size did not affect their size composition. This limpet lives not only in patches but also around them, where the bamacle $C$. challengeri attaches. There was no marked size difference between the limpets in and around the patches. This may be due to rather free movement of the limpets
Fig. 6. Typosyllis adamanteus kurilensis. Size distribution in each Mytilus patch

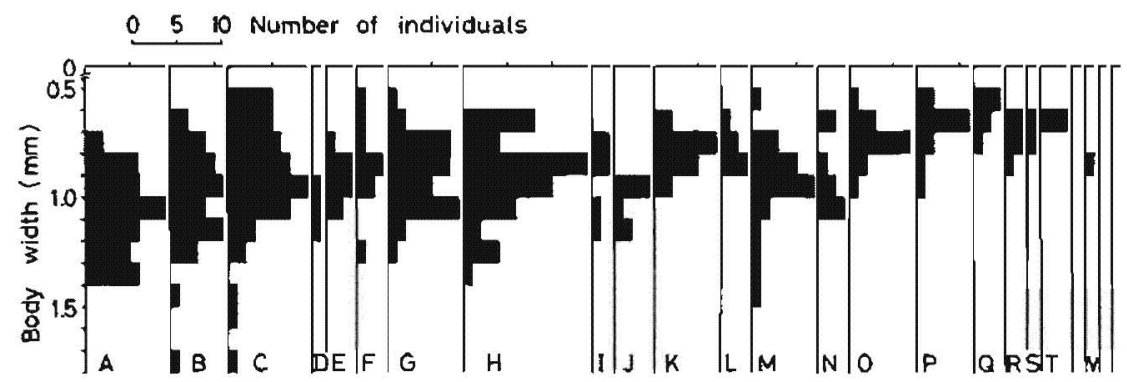




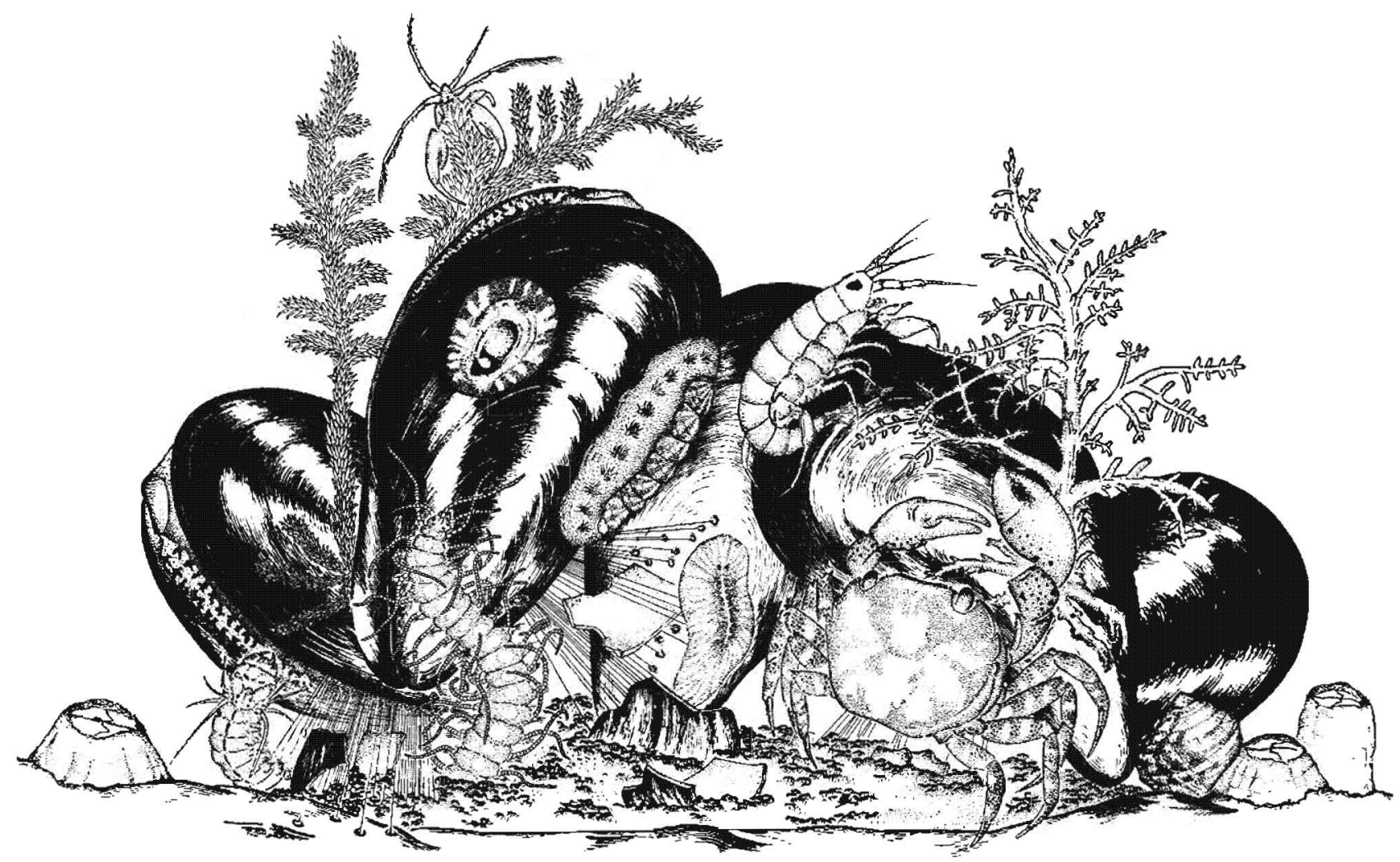

Fig. 7. Diagrammatic representation of cross-sectional view of a small Mytilus island. Many associated animals use several micro-habitats (shell surface of $M$. edulis, space in the patch, algae, sediments, etc.). Several inhabitants, Typosyllis adamanteus kurilensis, Perinereis cultrifera, Notoplana humilis, Collisella heroldi, Littorina brevicula, Acanthochiton rubrolineatus, Hyale grandicornis, Jassa falcata and Hemigrapsis sanguineus, and 2 kinds of algae, Sargassum and Laurencia are shown. Chthamalus challengeri are seen around the island

between patches and into the surrounding $C$. challengeri areas as described by Tsuchiya (1984). If so, there may be little possibility of the presence of Mytilus island influencing the growth of limpets.

It must be noted that sampling was made at daytime low tide. This means that the collected animals do not always represent the entire fauna of the patch, e.g. some animals were frequently observed to wander about the Chthamalus challengeri areas around the islands at high tide. These animals do not always return to their original islands. During high tide, exchange of inhabitants among patches may occur. However, such inter-patch exchange may not be very frequent because only 2 species, the amphipod Hyale grandicornis and the isopod Dynoides dentisinus, were seen around the patches at high tide. The latter is not very abundant in the islands surveyed, but is frequently found in larger islands on the lower intertidal (unpubl.). Large numbers of $H$. grandicornis were found among the Sargassum thunbergii which was removed from the larger islands (A and B) before scraping. Exchange of $H$. grandicornis among islands may occur frequently.
Acknowledgements. Thanks are due to staff members of the Marine Biological Station and Laboratory of Animal Ecology, Tohoku University, for advice, and to Professor R. T. Paine for reading of the manuscript. This study was partially supported by a grant-in-aid from the Ministery of Education, Japan (No. $57740346)$.

\section{LITERATURE CITED}

Abele, L. G. (1976). Comparative species richness in fluctuating and constant environments: coral-associated decapod crustaceans. Science, N. Y. 192; 461-463

Abele, L. G. (1979). The community structure of coral-associated decapod crustaceans in variable environments. In: Livingston, R. J. (ed.) Ecological processes in coastal and marine systems. Plenum Press, New York, p. 265-287

Connell, J. H. (1961a). Effect of competition, predation by Thais lapillus, and other factors on natural population of the bamacle Balanus balanoides. Ecol. Monogr. 31: 61-104

Connell, J. H. (1961b). The influence of interspecific competition and other factors on the distribution of the barnacle Chthamalus stellatus. Ecology 42: 710-723

Connell, J. H. (1970). A predator-prey system in the marine intertidal region. I. Balanus glandula and severat predatory species of Thais. Ecol. Monogr. 40: 49-78

Connell, J. H. (1972). Community interactions on marine rocky intertidal shores. Ann. Rev. Ecol. Syst. 3: 169-192 
Davies, G., Dare, P. J., Edwards, D. B. (1980). Fenced enclosures for the protection of seed mussels (Mytilus edulis L.) from predation by shore-crabs (Carcinus maenas [L.]). Fish. Res. Tech. Rep., MAFF Direct Fish. Res., Lowestoft 56: $1-14$

Dayton, P. K. (1971). Competition, disturbance and community organization: The provision and subsequent utilization of space in a rocky intertidal community. Ecol. Monogr. 41: 351-389

Dean, T. A. (1981). Structural aspects of sessile invertebrates as organizing forces in an estuarine fouling community. $\mathrm{J}$. exp. mar. Biol. Ecol. 53; 163-180

Emson, R. H., Faller-Fritsh, R. J. (1976). An experimental investigation into the effect of crevice availability on abundance and size-structure in a population of Littorina rudis (Maton): Gastropoda, Prosobranchia. J. exp. mar. Biol. Ecol. 23: 285-297

Frith, D. W. (1976). Animals associated with sponges at North Hayling, Hampshire. J. Linn. Soc. 58: 353-362

Gotelli, N. J., Abele, L. G. (1983). Community patterns of coral-associated decapods. Mar. Ecol. Prog. Ser. 13: 131-139

Hawkins. S. J. (1981). The influence of season and barnacles on the algal colonization of Patella vulgata exclusion areas. J. mar. biol. Ass, U. K. 61: 1-15

Hoshiai, T. (1960). Synecological study on intertidal communities IIl. An analysis of interrelation among sedentary organisms on artificially denuded rock surface. Bull. Mar. Biol. Stn Asamushi, Tohoku Univ. 10: 49-56

Hoshiai, T. (1965). Synecological study on intertidal communities VI. A synecological study on the intertidal zonation on the Asamushi coast area with reference to its reformation. Bull. Mar. Biol. Stn Asamushi, Tohoku Univ. 12: $93-126$

Keith, D. E. (1971). Substrate selection in caprellid amphipods of Southern California, with emphasis on Caprella californica Stimpson and Caprella equilibra Say (Amphipoda). Pacif. Sci. 25: 387-394

Kitting, C. L. (1980). Herbivore-plant interactions of individual limpets maintaining a mixed diet of intertidal marine algae. Ecol. Monogr. 50: 527-550

Lund, E. J. (1957). Self-silting, survival of the oyster as a closed system, and reducing tendencies of the environment of the oyster. Publ. Inst. mar. Sci., Univ. Tex. 4: 313-319

MacArthur, R. H. (1972). Geographical ecology: patterns in the distribution of species. Harper and Row, New York

MacArthur, R. H., Wilson, E. O. (1967). The theory of island biogeography. Prinston University Press, Prinston

Menge, B. A. (1976). Organization of the New England rocky intertidal community: role of predation, competition and environmental heterogeneity. Ecol. Monogr. 46: 355-393

Nishihira, M., Tsuchiya, M., Yamada, H. (1982). Ecological distribution of the red alga, Nemalion vermiculare Suringer, on the rocky shore at Asamushi, northem Japan: Effect of wave action, substrates and grazers. Bull. Mar. Biol. Stn Asamushi, Tohoku Univ. 17: 53-69
Osman, R. W. (1978). The influence of seasonality and stability on the species equilibrium. Ecology 59: 383-399

Paine, R. T. (1969). The Pisater-Tegula interaction: Prey patches, predator food preference and intertidal community structure. Ecology 50: 950-961

Paine, R. T. (1971). A short term experimental investigation of resource partitioning in a New Zealand rocky intertidal habitat. Ecology 52: 1096-1106

Paine, R. T. (1974). Intertidal community structure: Experimental studies on the relationship between a dominant competitor and its principal predator. Oecologia (Berl.) 15: 93-120

Paine, R. T., Vadas, R. L. (1969). The effect of grazing by sea urchin, Strongylocentrotus spp. on benthic algal populations. Limnol. Oceanogr. 14: 710-719

Pearse, A. S. (1950). Notes on the inhabitants of certain sponges at Bimini. Ecology 31: 149-151

Schoener, A. (1974a). Colonization curves for planar marine island. Ecology 55: 818-827

Schoener, A. (1974b). Experimental zoogeography: colonization of marine mini-island. Am. Nat. 108: 715-738

Schoener, A., Long, E. R., DePalma, J. R. (1978). Geographic variation in artificial island colonization curves. Ecology 59: $367-382$

Seed, R. (1976). Ecology. In: Bayne, B. L. (ed.) Marine mussels, their ecology and physiology. Cambridge University Press, Cambridge, p. 13-66

Southward, A. J. (1958). The zonation of plants and animals on rocky shores. Biol. Rev, 33: 137-177

Tsuchiya, M. (1979). Quantitative survey of intertidal organisms on rocky shores in Mutsu Bay, with special reference to the influence of wave action. Bull. Mar. Biol. Stn Asamushi, Tohoku Univ. 16: 69-86

Tsuchiya, M. (1980). Biodeposit production by the mussel Mytilus edulis L. on rocky shores. J. exp. mar. Biol. Ecol. 47: 203-222

Tsuchiya, M. (1983). Mass mortality in a population of the mussel Mytilus edulis $L$. caused by high temperature on rocky shores. J. exp. mar. Biol. Ecol, 66: 101-111

Tsuchiya, M. (1984). Effect of barnacle cover on the distributions of the limpet Collisella (Conoidacmea) heroldi (Dunker) and the periwinkle Littorina brevicula (Philippi) on the higher eulittoral zone. Bull. Mar. Biol. Stn Asamushi, Tohoku Univ., 17: 177-189

Underwood, A. J. (1980). The effects of grazing by gastropods and physical factors on the upper limits of distribution of intertidal macroalgae. Oecologia (Berl.) 46: 201-213

Underwood, A, J,, Jemekoff, O. (1981). Effects of interaction between algae and grazing gastropods on the structure of a low-shore intertidal algal community. Oecologia (Berl.) 48: $221-233$

Westinga, E., Hoetjes, P. C. (1981). The intrasponge fauna of Spheciospongia resparia (Porifera, Demospongiae) at Curaçao and Bonaire. Mar. Biol. 62: 139-150

Williamson, M. (1981). Island populations. Oxford University Press, Oxford 